\title{
Sağlık Sektöründe Duygusal Emeğin Kişilik ve Psikolojik Esenlikle İlişkileri
}

\section{The Relationship of Emotional Labor and Personality and Psychological Wellbeing in the Health Sector}

\author{
Habibe Tuğba EROL KORKMAZ*
}

\begin{abstract}
ÖZ
$\mathrm{Bu}$ çalışmada, sağlık sektörü çalışanları için duygusal emeğin öncülleri ve çıktıları incelenmiştir. Duygusal emek, yüzeysel duygusal emek ve derin duygusal emek olmak üzere iki boyut temelinde ele alınmıştır. Duygusal emeği yordamak amacıyla 5-faktörlü kişilik modeli (nevrotiklik, dışadönüklük, deneyime açıklık, uyumluluk, sorumluluk bilinci) kullanılmıştır. Duygusal emeğin çıktısı olarak ise çalışanların psikolojik esenliği (yaşam doyumu, iş doyumu, psikolojik semptomlar) değerlendirilmiştir. Likert-tipi ölçekler içeren anketler kullanılarak hastanelerde görev yapan 230 sağlık çalışanından veri toplanmıştır. Yürütülen bir dizi standart çoklu regresyon analizi sonucunda yüzeysel duygusal emeğin dişadönüklük (+) ve kısmen uyumluluk (-) kişilik boyutları tarafından yordandığı; derin duygusal emeğin ise dişadönüklük $(+)$, uyumluluk $(+)$ ve sorumluluk bilinci $(+)$ tarafından yordandığı tespit edilmiştir. Yüzeysel duygusal emek arttıkça yaşam doyumu azalmaktadır. Derin duygusal emeğin artması ve yüzeysel duygusal emeğin azalması, somatizasyon, depresyon ve hostilite semptomlarında azalma ile ilişkili bulunmuştur. Bu bulgular, derin duygusal emeğin çalışan esenliği için faydalı, yüzeysel duygusal emeğin ise zararlı olduğunu göstermiştir. Çalışma bulgularının alan yazındaki yeri, örgütlerdeki pratik uygulamalar açısından yapılabilecekler ve çalışmanın sınırlılıkları tartışılmaktadır.
\end{abstract}

Anahtar Kelimeler: Duygusal emek, kişilik, psikolojik esenlik, öznel iyi oluş

\begin{abstract}
Aim of this study was to investigate the antecedents and consequences of emotional labor in the health sector. Emotional labor was assessed based on the two dimensions of surface acting and deep acting. The five-factor model of personality (neuroticism, extraversion, openness to experience, agreeableness, and conscientiousness) was used to predict emotional labor. Employee psychological wellbeing (life satisfaction, job satisfaction, psychological symptoms) was used as a consequence of emotional labor. Questionnaires including Likert-type scales were used to collect data from 230 health workers employed in various hospitals. Standard multiple regression analyses revealed that surface acting was predicted by the personality dimensions of extraversion $(+)$ and agreeableness (-), while deep acting was predicted by extraversion (+), agreeableness (+), and conscientiousness $(+)$. Increase in surface acting was associated with a decrease in life satisfaction. Increase in deep acting and decrease in surface acting was accompanied by a decrease in symptoms of somatization, depression, and hostility. These findings indicate that deep acting promotes but surface acting deteriorates employee psychological wellbeing. Theoretical and practical implications of these findings and the limitations of the study are discussed.
\end{abstract}

Keywords: Emotional labor, personality, psychological wellbeing, subjective wellbeing

\footnotetext{
* Doç. Dr., Mersin Üniversitesi, Psikoloji Bölümü, tugbakorkmaz@ mersin.edu.tr, ORCID: 0000-0002-0696$931 \mathrm{X}$
} 


\section{GİRIŞ}

Müşterilere hizmet verilmesini içeren çeşitli işler, çalışanların duygusal emek sergileyerek olumlu duygularını ifade etmelerini ve olumsuz duygularını bastırmalarını gerektirmektedir (Hochschild, 1983). Bu konuda sağlık sektörü çalışanları diğer hizmet sektörü çalışanlarından ayrışmaktadır çünkü sağlık hizmeti almak isteyen hastalar ve hasta yakınları diğer müşterilerden farklı olarak acı ve kaygı içindedirler. Sağlık çalışanlarının görevleri arasında ameliyat etme, kan alma, acı verici bir tetkik yöntemi uygulama gibi rahatsız edici veya kaygı uyandırıcı işlemler yer almaktadır (Molinsky ve Margolis, 2005). Böyle bir bağlamda sergilenen duygusal emek, bir iletişim şirketinin çağrı merkezinde çalışan ve müşteri ile yüz yüze temas kurmayan bir kişiden beklenen duygusal emekten niteliksel olarak çok farklıdır. Hastalar şifa bulmayı istedikleri için çalışanlardan beklentileri hem yüksek ve hem de farklı bir niteliktedir. Bir kafede hizmet veren bir garsonun yapacağı olası bir hatanın sonucu pek önemli değilken, bir doktorun yapacağı olası bir hatanın sonucu hayatımıza mâl olabilir. İşlerinin doğası gereği sağlık sektörü çalışanlarının hasta ve hasta yakınları ile daha insanî ve yakın bir bağ kurması kaçınılmazdır (Fouquereau ve ark., 2019). Hastalarla etkileşime girerken çalışanların duygularını düzenlemesi ve uygun duygusal tepkileri yansıtması gerekmektedir. Dolayısıyla sağlı çalışanları için duygusal emek, işlerinin çok önemli bir unsurunu oluşturmaktadır. Bu nedenle sağlık sektörü özelinde duygusal emeğin incelenmesi önem taşımaktadır. Duygusal emeğin öncülleri ve sonuçları açısından sağlık sektörü ve diğer hizmet sektörü işleri arasında farklılıklar olması beklenmektedir. Bu çalışmanın odağında duygusal emek kavramı yer almaktadır. Yürütülen görgül araştırma kapsamında sağlık sektöründe görev yapan çalışanları içeren bir katılımcı grubu üzerinde duygusal emeğin öncülleri ve çıktıları incelenmiştir. Duygusal emeği yordayan öncül olarak 5-faktörlü kişilik yapısı kullanılmıştır. Duygusal emek tarafından yordanan çıktı olarak ise çalışanın psikolojik esenliği ele alınmıştır. Devam eden bölümde her bir kavrama yönelik tanımlar ve açıklamalar sunulmaktadır.

\section{Duygusal Emek}

Duygusal emek kavramı ilk olarak sosyolog Arlie Hochschild (1983) tarafindan hizmet sektöründe çalışan kişilerle ilgili olarak ortaya atılmıştır. Bizler bir kafeye gittiğimizde veya bir hastanede tedavi olurken bizimle ilgilenen garsonun veya hemşirenin bizi gülümseyerek karşılamasını ve bizim her türlü itiraz ve şikâyetimiz karşısında bile bu gülümseyen, kibar ve sevecen tavrından taviz vermemesini bekleriz. Bizim bu beklentimiz 
aslında söz konusu garson veya hemşire için bir çeşit iş gerekliliğidir ve performansının bir parçasıdır. Hochschild (1979) duygusal emeği, başkaları tarafından gözlemlenebilen belirli bir yüzsel veya bedensel duygu ifadesi yaratabilmek için hislerin yönetilmesi olarak tanımlamıştır. Dolayısıyla duygusal emek, çalışanın hizmet verirken kendi duyguları üzerinde denetim veya kontrol uygulamasını ve bunun karşılığında da ücret almasını içermektedir (Hochschild, 1983). Duygusal emek kavramını araştıran endüstri ve örgüt psikologları, kavramı özellikle duygu düzenleme çerçevesinde ele almışlar (örn., Grandey, 2000; Gross, 1998) ve örgütsel ve bireysel sonuçları üzerine çeşitli görgül çalışmalar yürütmüşlerdir (örn., Brotheridge ve Grandey, 2002; Grandey, Chi ve Diamond, 2013).

Hochschild'e (1983) göre duygusal emeğin iki farklı türü bulunmaktadır; yüzeysel duygusal emek ve derinlemesine duygusal emek. Yüzeysel duygusal emekte çalışan duygularını bastırarak veya rol yaparak kendisinden beklenen yönde ancak gerçekte hissetmediği şekilde davranışlar sergiler. Dolayısıyla kişinin duyguları değil, sadece davranışları değişmektedir. Derinlemesine duygusal emekte ise kişi müşterinin veya işinin kendisinden beklediği yönde duygusal ifadeler sergileyebilmek için çaba göstererek içsel duygularını değiştirmektedir (Grandey, Diefendorff ve Rupp, 2013). Grandey (2003) yüzeysel duygusal emeği "kötü niyetli rol yapma" olarak tanımlarken, derinlemesine duygusal emeği ise "iyi niyetli rol yapma" olarak betimlemiştir. Altta yatan süreçler farklılaşsa bile her iki duygusal emek türünde de amaç örgütün kazanımlarını (örn., satışlar ve müşteri memnuniyeti) artırabilmek için olumlu duygular sergileyerek müşterileri olumlu yönde etkilemektir (Tsai, 2001). Müşterilerin beklentisi kendilerine karşı olumlu duyguların ifade edilmesi olduğu için çalışanların olumsuz duygularıyla yüzeysel veya derinlemesine biçimde baş etmeleri söz konusudur. Gross'a (2015) göre duygusal emek boyutları temel duygu düzenleme stratejileriyle paralellik sergilemektedir. Örneğin yüzeysel duygusal emek davranışsal modülasyon (örn., bastırma ve abartma) stratejisine benzerken, derinlemesine duygusal emek ise bilişsel stratejilerle (örn., olayları tekrar değerlendirme, dikkati başka yöne odaklama) benzerlik göstermektedir. Diğer yandan Chi ve Grandey (2019) farklı duygusal emek boyutlarını Higgins’in (1998) “Düzenleme Odağı Kuramı” kapsamında öne sürdüğü iki güdüleyici sistemle eşleştirmektedir. Baskılama-odaklı düzenleme stratejileri istenmeyen sonuçlardan ve davranışlardan kaçınmayı içermekte ve aktivasyon-odaklı düzenleme stratejileri ise arzulanan hedef davranışların peşinden koşulmasını gerektirmektedir. Yüzeysel duygusal emek sahtelik, rol yapma ve bastırmayı barındırdığı için baskılama-odaklı strateji 
olarak; derin duygusal emek ise işyerindeki duygusal ifade kurallarına uyabilmek adına bilişin ve bakış açısının değiştirilmesini içerdiği için aktivasyon-odaklı strateji olarak siniflanmaktadir.

Duygusal emeğin örgütsel ve bireysel çıktılarına yönelik birçok meta-analiz çalışması yürütülmüştür (örn., Bono ve Vey, 2005; Hülsheger ve Schewe, 2011; Kammeyer-Mueller ve ark., 2013; Wang, Seibert ve Boles, 2011). Bu çalışmalar özellikle yüzeysel duygusal emeğin stresle ilişkili olduğunu ve çalışanın öznel iyi oluşuna zarar verdiğini göstermiştir. Derin duygusal emeğin ise öznel iyi oluşa zarar vermediği ve iş doyumu, örgütsel bağıllı, iş performansı ve müşteri memnuniyetiyle olumlu yönde ilişkileri olduğu ortaya konmuştur (Humphrey, Ashforth ve Diefendorff, 2015). Bu nedenle derin duygusal emeğin hem örgütsel hem de bireysel açıdan yüzeysel duygusal emeğe göre daha faydalı olduğu söylenebilir.

Diğer yandan duygusal emeğin öncüllerine yönelik görgül çalışmalar da bulunmaktadır. Bu araştırmaların bulguları olumsuz duygulanımın yüzeysel duygusal emek ile, olumlu duygulanımın ise derin duygusal emek ile ilişkili olduğunu göstermiştir (Brotheridge ve Grandey, 2002; Brotheridge ve Lee, 2003; Karim ve Weisz, 2011). Diefendorff, Croyle ve Gosserand'ın (2005) çalışmasında kişilik boyutları ve örgütün duygu ifade kuralları duygusal emeği yordamıştır. Yüzeysel duygusal emeğin en güçlü yordayıcıları nevrotiklik ve örgütün olumsuz duygu ifade kuralları iken derin duygusal emeğin en güçlü yordayıcıları ise uyumluluk ve müşteriyle etkileşimin süresidir.

Duygusal emek kavramını ele alan görgül çalışmalar çeşitli meslek grupları üzerinde yürütülmüştür. Bunlar arasında satış temsilcileri, çağrı merkezi çalışanları, öğretmenler, garsonlar, sosyal hizmet çalışanları, kreş öğretmenleri ve hemşireler örnek olarak sıralanabilir. Hülsheger ve Schewe (2011) duygusal emek kavramı üzerine yürüttükleri meta-analiz çalışmasında tespit ettikleri görgül çalışmaları, ele alınan meslek grubunun temsil ettiği hizmetin türüne göre iki gruba ayırmışlardır. Garsonluk, satış temsilciliği ve çağrı merkezi çalışanları gibi müşteri ile karşılaşan ancak derin ilişki kurulmasını gerektirmeyen işleri "hizmet karşılaşma" olarak etiketlemişlerdir. Hemşirelik, öğretmenlik, sosyal hizmet çalışanları gibi iş gereği etkileşime geçilen insanlarla daha derin bir ilişki kurulmasını gerektiren işleri ise "hizmet ilişkileri”" olarak adlandırmışlardır. Grandey ve Diamond da (2010) işin müşteri ile ne düzeyde bir etkileşim gerektirdiğinin duygusal emek çalışmalarında göz önünde bulundurulması gerektirdiğini vurgulamışlardır. Molinsky ve Margolis (2005) öne sürdükleri “zorunlu kötülük” kavramı ile bazı işlerde çalışanların görev gereği iyicil bir nihaî 
amaç uğruna kişilere duygusal veya fiziksel acı yaşattıklarına dikkat çekmişlerdir. Verdikleri örnekler arasında da sağlık hizmeti çalışanları önemli bir yer tutmaktadır. Doktorlar ve hemşireler hastanın sağlığına kavuşabilmesi için acı veren ameliyatlar ile tahlil ve tetkik işlemleri uygulayabilmektedirler. Tüm bunları yaparken özellikle sağlık sektöründe görev yapan hemşirelerin bakım verici ve besleyici bir tutumla hastalara yaklaşması ve hastanın moralini yükseltmeye yönelik diğer-odaklı duygu düzenleme davranışları da sergilemesi beklenmektedir (Erickson ve Grove, 2008). Sağlık sektöründe hizmet almayı bekleyen hastalar, diğer hizmet sektörü müşterilerinden farklı olarak acı, kaygı, panik ve korku içinde olmaları nedeniyle daha yoğun ve yakın bir ilgiye ihtiyaç duymaktadırlar (Kaya ve Yüceler, 2013; Venkatesh ve Balaji, 2013). Tüm bu unsurlar göz önünde bulundurulduğunda duygusal emek kavramı, sağlık sektörü çalışanları için işlerinin çok önemli bir parçasını oluşturmaktadır. Bu çalışmada da duygusal emeğin yoğun olarak kullanılmasını gerektiren sağlık sektörü çalışanları ele alınmıştır.

\section{Kișilik}

Endüstri ve örgüt psikolojisi alan yazınında bireyler arası farklılıkları ölçme ve değerlendirmede sıklıkla kullanılan kişilik yapısı 5-faktörlü kişilik modelidir (Hough ve Öneş, 2009). Costa ve McCrae (1992) tarafından oluşturulan 5-faktörlü kişilik modeli iş performansı (Barrick ve Mount, 1991), iş doyumu (Judge, Heller, \& Mount, 2002), liderlik (Judge, Bono, Ilies ve Gerhardt, 2002), risk alma eğilimi (Miner \& Raju, 2004), girişimcilik (Zhao ve Seibert, 2006), üretim karşıtı iş davranışı (Salgado, 2002), tükenmişlik ve işe adanmışlık (Kim, Shin ve Swanger, 2009) gibi birçok örgütsel kavramın yordayıcısı olarak araştırmalarda yaygın olarak kullanılmıştır.

Beş-faktörlü kişilik modelinde yer alan boyutlar nevrotiklik, dışadönüklük, deneyime açıklık, uyumluluk ve sorumluluk bilincidir. Nevrotiklik boyutunda yüksek olan kişiler strese daha yatkındırlar; kaygı, üzüntü, kızgınlık gibi olumsuz duyguları deneyimleme eğilimleri daha fazladır ve öz bilinç ve dürtüsellik düzeyleri duygusal açıdan dengeli kişilere kıyasla daha yüksektir. Dışadönük kişiler daha aktif olan, uyarılma ihtiyacı yüksek olan, sosyal etkileşim, sıcaklık ve sokulganlık arayışında olan ve içedönük kişilere kıyasla daha sıklıkla olumlu duygular deneyimleme eğiliminde olan bireylerdir. Deneyime açıklık boyutunda yüksek olan kişiler hislere ve duygulara açıktırlar; sanata ve güzelliklere düşkündürler; hayal dünyaları zengindir; ıraksak düşünebilirler; maceraperesttirler ve deneyime kapalı kişilere kıyasla daha liberal bir dünya görüşüne sahiptirler. Uyumluluk kişilik boyutunda yüksek olan 
kişiler şefkatli, sade, alçakgönüllü, güvenilir, uyma eğilimi gösteren ve diğerkâm bireyler olup insan ilişkilerinde geçimli kişilerdir. Sorumluluk bilinci yüksek olan bireyler ise yetkinliğe önem veren, düzenli, başarma güdüsü yüksek, öz disiplinli, azimli ve görevlerini zamanında yerine getiren kişilerdir (Costa ve McCrae, 1989, 1992). Watson ve Clark'1n (1992) öne sürdüğü pozitif ve negatif duygulanım boyutlarıyla kişilik boyutları arasındaki ilişkilere yönelik çalışmalar, nevrotikliğin olumsuz duygulanım ile (Miller, Vachon ve Lynam, 2009), dışadönüklüğün ise olumlu duygulanım ile (Burger ve Caldwell, 2000) güçlü ilişkilere sahip olduğunu ortaya koymuştur. Baranczuk (2019) kişilik boyutları ve duygu düzenleme stilleri arasındaki ilişkileri inceleyen görgül çalışmaların bir meta-analizini yürütmüştür. Bulgularına göre nevrotiklik arttıkça duyguları bastırma, ruminasyon ve kaçınma gibi etkisiz duygu düzenleme eğilimleri artmaktadır. Yüksek dışadönüklük ve sorumluluk bilinci ile düşük nevrotiklik ise tekrar değerlendirme, bilinçli farkındalık ve problem çözme gibi etkili duygu düzenleme eğilimleriyle olumlu yönde ilişki sergilemektedir.

\section{Çalışanın Psikolojik Esenliği}

Pozitif psikoloji akımının yükselişiyle beraber artık günümüzde esenliğin veya psikolojik sağglığın tanımı da değişmiştir. Eskiden esenlik, herhangi bir rahatsızlı̆ıın olmaması olarak tanımlanırken güncel yazında esenlik, kişinin hem olumlu hislere hem de olumlu bir işlevselliğe işaret eden semptomlara sahip olması olarak betimlenmektedir (Keyes, 2006). Her iki kriteri de sağlayan kişiler gelişmekteyken (flourishing), bu kriterleri karşılayamayan kişiler ise cansızlaşmaktadırlar (languishing) (Keyes, 2007). Diğer yandan esenliğin bir parçası olan öznel iyi oluş kavramı üzerine çalışan araştırmacılar yüksek olumlu duygulanım, düşük olumsuz duygulanım ve yüksek yaşam doyumunun iyi oluşu yansıttığını öne sürmektedirler (Busseri, Sadava ve Decourville, 2007; Diener, Suh, Lucas ve Smith, 1999). Çalışan öznel iyi oluşunu ele alan bazı araştırmalarda kavram işyeri bağlamına uyarlanarak işteyken hissedilen olumlu ve olumsuz duygulanım ile iş doyumu ölçülmektedir (Page ve Vella-Brodrick, 2009). Diğer araştırmalarda ise sadece çalışanların işte yaşadığı duygulara odaklanılmakta (Warr, 2006) veya algılanan ruh sağlığı düzeyi veya psikosomatik semptomlar değerlendirilebilmektedir (Arnold, 2017). Çalışan duygularını ölçmek için kimi araştırmacılar iki boyutlu PANAS (Watson, Clark ve Tellegen, 1988) yapısını kullanırken kimileri ise daha kapsamlı yapıları tercih etmektedirler. Örneğin Daniels'1n (2000) işyerinde duygular modelinde 5 duygu ekseni yer almaktadır: kayg1-rahatlık, depresyon-memnuniyet, sıkılmış-ilgili, yorgun-coşkulu ve öfkeli-sakin. 
Çalışan esenliğinin çeşitli çıktıları bulunmaktadır. Psikolojik esenliği yükssek olan kişiler fiziksel olarak daha sağlıklı olmakta (örn., Wright, Cropanzano, Bonett ve Diamond, 2009), özel yaşamlarında daha mutlu hissetmekte ve daha uzun yaşamaktadırlar (Cartwright ve Cooper, 2008). Wright ve Cropanzano (2000) yürüttükleri görgül çalışmada, çalışanın psikolojik esenliği ve iş performansı arasında olumlu bir ilişki olduğunu kanıtlamışlardır.

Diğer yandan çalışanın psikolojik esenliğinin öncülleri de çeşitli araştırmalara konu olmuştur. Psikolojik esenliği yordayan değişkenler arasında dönüştürücü liderlik (Arnold, 2017), yöneticinin çalışana yönelik tutum ve davranışları (Gilbreath ve Benson, 2004), algılanan örgütsel destek (Panaccio ve Vandenberghe, 2009), işin anlamı ve perspektif alma (Arnold ve Walsh, 2015), duygusal zekâ (Carmeli, Yitzhak-Halevy ve Weisberg, 2009), yüzeysel duygusal emek (Riforgiate, Howes ve Simmons, 2021) ve örgütsel adalet (Heffernan ve Dundon, 2016) yer almaktadır. Araştırmalar ayrıca kişiliğin de bireylerin dayanıklılık ve psikolojik esenliklerini yordamada önemli olduğunu göstermektedir (DeNeve ve Cooper, 1998; Lucas ve Diener, 2015). Özellikle kişiliğin dışadönüklük boyutu iyi oluşa olumlu yönde katkıda bulunmaktadır (Athota, Budhwar ve Malik, 2020; Keyes, Shmotkin ve Ryff, 2002).

\section{Çalışmanın Amacı ve Hipotezleri}

Bu çalışmanın iki temel amacı bulunmaktadır. Birinci amacı sağlık sektöründe çalışan kişilerin sergiledikleri derin duygusal emeğin ve yüzeysel duygusal emeğin hangi kişilik özellikleri tarafından yordandığını incelemektir. İkinci amaç ise sağlık sektöründe hizmet veren çalışanların derin ve yüzeysel duygusal emek düzeyleri ile psikolojik iyi oluşları arasındaki ilişkileri ortaya koymaktır. Çalışma kapsamında kişilik kavramının işevuruk tanımının yapılmasında Costa ve McCrae (1992) tarafından oluşturulan 5-faktörlü kişilik modeli temel alınmıştır. Çalışanın psikolojik iyi oluşu ise yaşam doyumu, iş doyumu ve psikolojik semptomlar (somatizasyon, depresyon ve hostilite) aracılığı ile ölçümlenmiştir.

Kişilik boyutları üzerine yürütülmüş geçmiş çalışmalar, 5-faktörlü kişilik boyutlarından dışadönüklüğün olumlu duygulanım ile paralellik sergilediğini göstermektedir. $\mathrm{Bu}$ kişiler insan ilişkilerinde daha enerjik ve sosyal davranışlar sergilemekte, daha kolay yakınlık kurabilmekte ve olumlu duyguları daha sık hissetmektedirler (Costa ve McCrae, 1992). Bu nedenle dışadönük kişilerin duygularını düzenlemede daha başarılı olabileceği ve bu kişilik boyutunun derin duygusal emeği olumlu yönde yordayacağı öngörülmektedir. Kişiliğin nevrotiklik alt boyutu ise olumsuz duygulanım ile güçlü ilişkilere sahiptir (Magnus, Dieter, Fujita ve Pavot, 1993). Dolayısıyla bu kişilik özelliğine sahip kişilerin duygu 
düzenleme becerilerinin görece zayıf olması söz konusudur. $\mathrm{Bu}$ nedenle nevrotiklik boyutunun yüzeysel duygusal emeğin anlamlı bir yordayıcısı olması beklenmektedir. Diğer yandan kişiliğin uyumluluk boyutu diğer insanlarla yakın ve geçimli ilişkiler kurabilmeyi yansıtmaktadır. McCrae ve Costa (1991) uyumluluk ile mutluluk ve yaşam doyumu arasında olumlu ilişkiler tespit etmişlerdir. Uyumlu kişilerin diğer insanlarla iyi ilişkileri olması onların esenliğine katkıda bulunmaktadır. $\mathrm{Bu}$ nedenle uyumluluğun derin duygusal emeğin yordayıcısı olabileceği öngörülmektedir. Sorumluluk bilinci yüksek olan çalışanların görevlerinin gereklerini başarılı biçimde yerine getirme konusunda motivasyonlarının ve azimlerinin yüksek olması beklenmektedir (Judge, Heller ve Mount, 2002). Dolayısıyla bu kişiler duygusal emeğin daha etkili bir türü olan derin duygusal emeği etkili biçimde sergileme konusunda eğilim sergileyebilirler. Kişiliğin deneyime açıklık boyutunun ise kavramsal olarak duygusal emek ile ilişkili olmadığı ve bu nedenle ne derin duygusal emek için ne de yüzeysel duygusal emek için yordayıcı bir gücü bulunmadığı düşünülmektedir. $\mathrm{Bu}$ gerekçeler doğrultusunda araştırmanın kişilik boyutları ile ilişkili hipotezleri şunlardır:

$\mathrm{H}_{1}$ : Kişiliğin dışadönüklük boyutu derin duygusal emeği anlamlı düzeyde yordamaktadır.

$\mathrm{H}_{2}$ : Kişiliğin nevrotiklik boyutu yüzeysel duygusal emeği anlamlı düzeyde yordamaktadır.

$\mathrm{H}_{3}$ : Kişiliğin uyumluluk boyutu derin duygusal emeği anlamlı düzeyde yordamaktadır.

$\mathrm{H}_{4}$ : Kişiliğin sorumluluk bilinci boyutu derin duygusal emeği anlamlı düzeyde yordamaktadır.

Geçmiş çalışmalar yüzeysel ve derin duygusal emeğin çalışan iyi oluşu üzerinde asimetrik etkilere sahip olduğunu göstermiştir (Humphrey, Ashforth ve Diefendorff, 2015). Çeşitli meta-analiz çalışmalarına göre yüzeysel duygusal emek, stres ve tükenmişlik ile ilişkili iken derin duygusal emek bu gibi kavramlarla ilişki sergilememekte, hatta aksine iş doyumu ve müşteri memnuniyeti gibi örgütsel çıktılarla olumlu ilişkiler kurmaktadır (Wang, Seibert ve Boles, 2011). Bu nedenle bu çalışmada da psikolojik iyi oluşun derin ve yüzeysel duygusal emek tarafindan benzer doğrultuda yordanması beklenmektedir. Duygusal emek ve psikolojik iyi oluşa yönelik araştırma hipotezleri aşağıda belirtilmiştir:

$\mathrm{H}_{5}$ : Derin duygusal emek yaşam doyumunu olumlu yönde yordamaktadır.

$\mathrm{H}_{6}$ : Derin duygusal emek iş doyumunu olumlu yönde yordamaktadır.

$\mathrm{H}_{7}$ : Derin duygusal emek psikolojik semptomları olumsuz yönde yordamaktadır.

$\mathrm{H}_{8}$ : Yüzeysel duygusal emek yaşam doyumunu olumsuz yönde yordamaktadır. 
$\mathrm{H}_{9}$ : Yüzeysel duygusal emek iş doyumunu olumsuz yönde yordamaktadır.

$\mathrm{H}_{10}$ : Yüzeysel duygusal emek psikolojik semptomları olumlu yönde yordamaktadır.

\section{YÖNTEM}

\section{Araştırmanın Deseni}

Bu çalışmada korelasyona dayalı bir araştırma yöntemi benimsenmiştir. Bu kapsamda ölçülmesi hedeflenen kavramlara yönelik ölçekler bir anket kapsamında derlenerek katılımcılara uygulanmıştır. Ölçümü alınan değişkenler arasındaki ilişkiler regresyon analizi ile incelenmiştir. Araştırmanın birinci amacı doğrultusunda ele alınan bağımlı değişkenler duygusal emeğin boyutları olan derin duygusal emek ve yüzeysel duygusal emektir. $\mathrm{Bu}$ bağımlı değişkenleri yordamak için kullanılan bağımsız değişkenler ise kişiliğin 5 boyutudur; nevrotiklik, dışadönüklük, uyumluluk, sorumluluk bilinci ve deneyime açıklık. Araştırmanın ikinci amacı doğrultusunda ele alınan bağımlı değişkenler ise psikolojik esenliğin göstergeleri olan yaşam doyumu, iş doyumu ve psikolojik semptomlardır (somatizasyon, depresyon ve hostilite). Bu bağımlı değişkenleri yordamak için kullanılan bağımsız değişkenler ise duygusal emeğin iki boyutudur: derin duygusal emek ve yüzeysel duygusal emek.

\section{Katılımcilar}

Araştırmaya Mersin ilinde hizmet veren çeşitli özel hastaneler ve devlet hastanelerinde görev yapan sağlık personeli katılmıştır. Çalışmada yer alan kişiler arasında doktor, hemşire, ebe, tıbbi sekreter ve tıbbi teknisyenler yer almaktadır. Veriler Likert-tipi ölçeklerden oluşan bir anket aracılığıyla toplanmıştır. Her bir anket eşliğinde katılımcılara birer zarf teslim edilmiş ve katılımcılar doldurdukları anketleri kapalı zarfların içinde anonim olarak teslim etmiş̧lerdir. Başlangıçta toplam 400 anket katılımcılara dağıtılmıştır ancak doldurulmayan veya fazla miktarda eksik bilgi barındıran anketler elendiğinde 264 kişilik bir veri seti elde edilmiştir. Veri seti üzerinde tek-değişkenli ve çok-değişkenli uç değer analizi yürütülerek uç değer içeren kişiler veri setinden çıkarılmıştır. Böylece çalışmada incelenen değişkenler arasındaki ilişkileri test etmede kullanılabilecek 230 kişilik bir veri seti oluşturulmuştur. Katılımcıların \%71,4'ü kadın ve \%28,6'sı erkektir. Yaş ve çalışma süresinin ortalaması sirasiyla $30,58(\mathrm{SS}=9.16)$ ve 4,96'd1r $(\mathrm{SS}=5.35)$.

\section{Ölçme Araçları}

5-Faktörlü Kişilik Modeli. Kişilik boyutlarını ölçmek amacıyla John, Donahue ve 
Kentle'ın (1991) geliştirdiği Beş Büyük Kişilik Ölçeği (BFI) kullanılmıştır. Ölçeğin Türkçe uyarlaması Sümer ve Sümer (2005) tarafından yapılmıştır. Ölçekte yer alan 44 madde ile nevrotiklik (örn., bunalımlı, gergin olabilen, çok endişelenen), dışadönüklük (örn., konuşkan, atılgan, enerji dolu), deneyime açıklık (örn., orijinal, derin düşünen, hayal gücü yüksek), uyumluluk (örn., yardımsever, affedici, başkalarına güvenen) ve sorumluluk bilinci (örn., işini tam yapan, dağınık-ters madde, tembel-ters madde) ölçülmüştür. Katılımcılardan her bir maddeye kendilerini yansıtması açısından ne derece katıldıklarını 5-basamaklı (1=Hiç katılmıyorum, 5=Kesinlikle katılıyorum) Likert-tipi ölçek üzerinde belirtmeleri istenmiştir. Kişilik boyutlarının iç-tutarlılık katsayıları sırasıyla .68, .72, .75, .67 ve .74'tür.

Duygusal Emek. Duygusal emeği ölçmek için Öz-Ünler (2007) tarafından Türkçe uyarlaması yapılan 19 maddelik Duygusal Emek Davranışları Ölçeği kullanılmıştır. Bu ölçek Grandey (1999) ve Brotheridge ve Lee'nin (1998) ölçek çalışmaları temel alınarak geliştirilmiştir. Ölçekte rol yapma (örn., "Hissetmediğim duyguları hissediyormuş gibi yaparım.”), bastırma (örn., "Genellikle o sırada hissettiğim gerçek duygularımı gizlemeye çalışırım.”) ve derinlemesine davranma (örn., "Hastayla etkileşim sırasında, benim duygularıma ters gelse bile, o sırada işim icabı göstermem gereken duygu ne ise onu hissetmeye çalışırım.”) alt boyutlarına yönelik maddeler bulunmaktadır. Katılımcılara her bir maddede sunulan davranışı hasta ve hasta yakınlarıyla etkileşirken hangi sıklıkla sergilediklerini 6-basamaklı (1=Hiçbir zaman, 6=Her zaman) Likert-tipi ölçek üzerinde belirtmeleri istenmiştir. Ölçek maddeleri üzerinde yürütülen keşifsel faktör analizi sonucunda bazı maddelerin hem yüzeysel hem de derin duygusal emek faktörlerine aynı anda yüklendiği tespit edilmiştir. Bu gibi maddeler (örn., "Sinirli bir hastayla konuşurken onların aramızda geçenlere değil başka bir şeye hiddetlendiklerini düşünürüm.”, "Hastayla/hasta yakınıyla etkileşim sırasında kurumumun benden göstermemi istediği duyguları yansıtabilmek için rol yaparım.”) çıkarılarak her bir faktörün genel puanı ve Cronbach Alpha güvenirlik değeri hesaplanmıştır. Bu doğrultuda yüzeysel duygusal emeğin (5 madde) güvenirlik katsayısı .61, derin duygusal emeğinki (9 madde) ise .82 'dir. Spearman Brown formülü kullanılarak yüzeysel duygusal emeğin 9 maddelik versiyonu için elde edilen düzeltilmiş güvenirlik katsayısı ise .74'tür.

Psikolojik Esenlik. Psikolojik esenliğin değerlendirilmesi için birden fazla psikolojik kavram ölçülmüştür. Bunlar yaşam doyumu, iş doyumu ve psikolojik semptomlardır (somatizasyon, depresyon ve hostilite). Yaşam doyumunun ölçümünde Deiner, Emmons, 
Larsen ve Griffin (1985) tarafından geliştirilen ve Yetim (1993) tarafindan Türkçe uyarlaması yapılan 5 maddelik (örn., "Yaşamım beni tatmin ediyor.") Yaşam Doyumu Ölçeği kullanılmıştır. Katılımcıların iş doyumunu ölçmek için Hackman ve Oldham (1975) tarafından geliştirilmiş olan ve Bilgiç (1999) tarafından Türkçeye uyarlanan iş doyumu ölçeğinin 3 maddesi kullanılmıştır (Örn., “Genel olarak konuşmak gerekirse, işim beni çok tatmin ediyor.”). Yönergede katılımcılardan sunulan her bir maddeye ne derece katıldıklarını 5-basamaklı (1=Hiç katılmıyorum, 5=Kesinlikle katılıyorum) Likert-tipi ölçek üzerinde belirtmeleri istenmiştir. Ölçeklerin iç tutarlılık katsayıları yaşam doyumu için .82 ve iş doyumu için .72'dir.

Psikolojik semptomların ölçülmesi amacıyla Şahin ve Durak (1994) tarafindan geliştirilen Kısa Semptom Envanteri'nin somatizasyon (örn., "Mide bozukluğu, bulantı"), depresyon (örn., "Gelecekle ilgili umutsuzluk duyguları”) ve hostilite (örn., "Çok kolayca kızıp öfkelenme”) alt ölçeklerinden maddeler kullanılmıştır. Katılımcılardan son bir hafta içinde yaşadıkları belirti ve şikâyetleri 5-basamaklı ( $0=$ Hiç yok, 5=Çok fazla var) Likert-tipi ölçek üzerinde belirtmeleri istenmiştir. Ölçeklerin Cronbach Alpha değerleri sırasıyla .86, .86 ve .81 'dir.

\section{BULGULAR}

Analizlerin başlangıcında SPSS programı kullanılarak araştırmada yer alan değişkenler için betimleyici istatistikler hesaplanmıştır. Tablo 1'de değişkenlere ait ortalama, standart sapma ve ölçek güvenirlik katsayıları ile değişkenler arasındaki korelasyonlar sunulmaktadır. Bu tabloda görüleceği gibi değişkenler arasındaki korelasyonlar beklenilen doğrultudadır.

\section{Tablo 1}

Betimleyici istatistiklerin ardından bir dizi standart çoklu regresyon analizi yürütülmüştür. İlk olarak 5 kişilik boyutu bağımsız değişken olarak kullanılarak duygusal emek bağımlı değişkeni yordanmıştır. Duygusal emeğin her bir boyutu için analizler ayrı ayrı yürütülmüştür. Analiz sonuçlarına göre kişilik boyutları yüzeysel duygusal emeği ( $F=3.79$, $p<.01)$ ve derin duygusal emeği $(\mathrm{F}=15.27, p<.001)$ anlamlı düzeyde yordamaktadır. Kişilik boyutları tek tek incelendiğinde (bkz. Tablo 2) yüzeysel duygusal emeği dişadönüklük ve kısmen uyumluluk boyutunun yordadığı görülmektedir. Dışadönüklük arttıkça ve uyumluluk 
azaldıkça yüzeysel duygusal emek artmaktadır. Araştırmanın hipotezlerinde yüzeysel duygusal emeğin nevrotiklik boyutu tarafından yordanması öngörülmüştür ancak bulgulara göre $\mathrm{H}_{2}$ desteklenmemiştir.

Analiz sonuçlarına göre derin duygusal emek ise dişadönüklük, uyumluluk ve sorumluluk bilinci tarafından anlamlı biçimde yordanmaktadır (bkz. Tablo 2). Bu kişilik özelliklerinde yüksek olan kişiler, düşük olan kişilere kıyasla daha fazla derin duygusal emek sergilemektedirler. Böylece bulgulara göre $\mathrm{H}_{1}, \mathrm{H}_{3}$ ve $\mathrm{H}_{4}$ desteklenmiştir.

Tablo 2

Tablo 3

Tablo 4

Regresyon analizlerinde ikinci adımda duygusal emek boyutları bağımsız değişken olarak kullanılarak çalışanların psikolojik esenliği yordanmıştır. Psikolojik esenliğin göstergeleri olarak yaşam doyumu, iş doyumu ve psikolojik semptomlar bağımlı değişkenler olarak ele alınmıştır. Analiz sonuçları Tablo 3 ve Tablo 4'te sunulmaktadır. Yaşam doyumu ve iş doyumu için test edilen regresyon modelleri istatistiksel açıdan manidar değildir $(\mathrm{F}=2.82, p=.06 ; \mathrm{F}=.79, p=.46)$ ancak yaşam doyumu modeli kısmen anlamlıdır $(p<.10)$. Bağımsız değişkenlerin regresyon katsayıları incelendiğinde ise yüzeysel duygusal emeğin yaşam doyumunu anlamlı düzeyde yordadığı görülmektedir (bkz. Tablo 3). Yüzeysel duygusal emek arttıkça yaşam doyumu azalmaktadır. Böylece yaşam doyumu ve iş doyumu ile ilişkili araştırma hipotezlerinden $\mathrm{H}_{5}, \mathrm{H}_{6}$ ve $\mathrm{H}_{9}$ desteklenmezken, $\mathrm{H}_{8}$ desteklenmiştir.

Psikolojik semptomların her biri için yürütülen regresyon modelleri anlamlıdır. Yüzeysel duygusal emek arttıkça ve derin duygusal emek azaldıkça somatizasyon $(\mathrm{F}=7.17$, $p<.01)$, depresyon $(\mathrm{F}=7.89, \quad p<.001)$ ve hostilite $(\mathrm{F}=9.76, \quad p<.001)$ artış eğilimi göstermektedir. Sonuç olarak araştırma hipotezlerinden $\mathrm{H}_{7}$ ve $\mathrm{H}_{10}$ desteklenmiştir.

\section{TARTIŞMA}

Bu çalışmada sağlık sektöründe hizmet veren çalışanlar için özellikle önemli bir 
kavram olan duygusal emeğin öncülleri ve çıktıları incelenmiştir. Beş-faktörlü kişilik yapısı öncül olarak ele alınırken duygusal emeğin çıktısı olarak psikolojik esenlik ölçümlenmiştir. Kişiliğin dışadönüklük ve uyumluluk boyutları hem yüzeysel hem de derin duygusal emeği yordarken, sorumluluk bilinci boyutu sadece derin duygusal emeği yordamıştır. Dışadönüklük arttıkça yüzeysel ve derin duygusal emek artma eğilimindedir. Uyumluluk arttıkça derin duygusal emek artarken yüzeysel duygusal emek ise azalmaktadır. Sorumluluk bilinci yüksek olan kişiler, düşük olan kişilere kıyasla daha fazla derin duygusal emek sergilemektedirler. Ancak çalışmanın nevrotiklik boyutu ile ilişsili hipotezi desteklenmemiştir. Nevrotikliğin yüzeysel duygusal emeği yordaması beklenirken söz konusu değişkenin regresyon katsayısı istatistiksel olarak anlamsız bulunmuştur. Nevrotiklik boyutunun duygusal emek boyutları ile korelasyon katsayıları incelendiğinde yüzeysel duygusal emek ile ilişkili olmadı̆̆ı ancak derin duygusal emek ile negatif yönde ilişkili olduğu görülmektedir. Nevrotiklik düzeyi arttıkça çalışanlar daha az derin duygusal emek sergileme eğilimindedirler.

Çalışma bulgularının bir kısmı geçmiş görgül çalışmalar ile paralellik gösterirken, bir kısmı farklılaşmaktadır. Bunun nedeni farklı görgül çalışmalarda ele alınan iş gruplarının içeriklerinin ve gerektirdiği duygusal emeğin niteliğinin farklılaşması olabilir. Duygusal emek kavramını ele alan çalışmaların kimileri öğretmenler üzerinde, kimileri sağlık personeli üzerinde, kimileri satış personeli üzerinde, bazıları ise karma meslek grupları üzerinde yürütülmüştür. Bu çeşitli meslek gruplarının duygusal ifade kuralları farklılık arz edebilir ve bu da araştırmalarda elde edilen verilerdeki ilişki örüntülerini etkiliyor olabilir. Diefendorff, Croyle ve Gosserand'ın (2005) yürüttükleri araştırmada çeşitli hizmet sektörü işlerinde (örn., satış personeli, çocuk bakıcılığı, sekreterlik) çalışan kişilerden karma olarak veri toplanmıştır. Çalışma bulgularına göre yüzeysel duygusal emek dışadönüklük, nevrotiklik, uyumluluk ve sorumluluk bilinci tarafindan yordanırken derin duygusal emek sadece uyumluluk boyutu tarafindan yordanmıştır. Kiffin-Peterson, Jordan ve Soutar (2011) tarafından yürütülen çalışmada da farklı sektörlerden karma bir katılımcı grubu kullanılmıştır ve bulgulara göre yüzeysel duygusal emek sadece nevrotiklikle ilişkiliyken derin duygusal emek ise dışadönüklük ve uyumluluk ile ilişkili bulunmuştur. Ulusal yazında Aslan ve Arı (2018) tarafından yürütülen araştırmada bankacılık sektöründe görevli kişiler çalışmaya katılmıştır ve sadece deneyime açıklık ve derin duygusal emek anlamlı ilişki göstermiştir. Beğenirbaş ve Yalçın (2012) ise eğitim, sağlık, finans ve güvenlik sektörlerinde hizmet veren kişilerden veri topladıkları araştırmalarında yüzeysel duygusal emek için nevrotikliği, derin duygusal emek 
için sorumluluk bilincini anlamlı yordayıcı kişilik özellikleri olarak rapor etmişlerdir. Dolayısıyla mevcut çalışmanın bulguları da sağlık sektörü çalışanlarını yansıtan bir bulgu olarak ele alınıp değerlendirilmelidir. Farklı çalışma bulguları arasındaki tutarsızlıkları açıklayabilecek bir diğer neden ise farklı çalışmalarda kişiliği ve duygusal emeği değerlendirmek için farklı ölçme araçlarının kullanılması olabilir. Dolayısıyla gelecekte kişilik ve duygusal emek arasındaki ilişkileri inceleyen çalışmaların bir meta-analizinin yapılması ve bu ilişkileri düzenleyen moderatörlerin de meslek türü ve ölçek türü gibi değişkenleri ele alması faydalı olacaktır.

Genel olarak hizmet sektöründe çalışan personel için hangi kişilik özelliklerinin duygusal emeği yordadığının belirlenmesi oldukça anlamlıdır. Duygusal servisin (affective delivery) hizmet sektörü işleri için ayrı bir önemi bulunmaktadır çünkü duygusal servis müşterilerin çalışanları ne derece sıcak, ilgili ve özenli algılayacaklarını ve müşteri memnuniyetini belirlemektedir (Tsai ve Huang, 2002). Dolayısıyla hizmet sektörü çalışanlarının performans göstergelerinden bir tanesi duygusal servis başarısıdır (Chi ve Grandey, 2019). Çeşitli görgül araştırma bulgularına göre yüzeysel duygusal emek, duygusal servis performansıyla negatif ilişkiye sahipken derin duygusal emek, duygusal servis performansıyla pozitif bir ilişkiye sahiptir (Chi ve Grandey, 2019; Gabriel ve Diefendorff, 2015). Ayrıca duygusal emek, çalışanların öznel iyi oluşunu olumsuz etkileyerek tükenmişlik düzeylerini artırabilmekte ve bu da sonuç olarak çalışanların daha fazla üretim karşıtı davranışlar sergilemesine ve müşteri memnuniyetinin düşmesine neden olabilmektedir (Chi ve Grandey, 2019; Hülsheger ve Schewe, 2011). Dolayısıyla, duygusal emeğin müşterilerin algıları üzerindeki etkileri göz önünde bulundurulduğunda hizmet sektöründe faaliyet gösteren işletmelerin hizmet personeli seçiminde özenli olması gerekmektedir. Daha fazla derin duygusal emek sergileyebilecek ve daha az yüzeysel emek sergileyecek kişilerin işe alımının tercih edilmesi örgütler açısından olumlu olacaktır. $\mathrm{Bu}$ araştırmanın bulguları doğrultusunda sağl1k sektöründe görev alacak personelin seçiminde uygulanacak kişilik değerlendirme prosedürleri sonucunda dışadönüklük, uyumluluk ve sorumluluk bilinci kişilik boyutlarında görece yüksek puan alan adayların işe alınmaları duygusal servis performansını artırabilir. Uyumluluk boyutunun yüzeysel emek ile negatif yönde ilişkili bulunması ve derin duygusal emek ile pozitif yönde ilişkili bulunması, bu kişilik boyutunun sağlık sektörü için özellikle önem taşıdığına işaret etmektedir. İnsan ilişkilerine önem veren, geçimli ve yakın ilişkiler kurabilen uyumlu çalışanların hastalarla ve hasta yakınlarıyla daha etkili iletişim 
kurarak yüksek düzey duygusal servis performansı sergilemesi mümkün olabilir.

Çalışmanın duygusal emek ve çalışanın psikolojik esenliği arasındaki ilişkilere yönelik bulgularının bir kısmı beklenilen doğrultudadır. Duygusal emek ile yaşam ve iş doyumu arasındaki ilişkilerde sadece yüzeysel duygusal emek ve yaşam doyumu arasındaki ilişki anlamlı bulunmuştur. Yüzeysel duygusal emek arttıkça yaşam doyumu azalmaktadır. İş doyumu ne yüzeysel ne de derin duygusal emek tarafindan yordanamamıştır. Bu bulgu kısmen literatür ile paralellik göstermektedir. Hülsheger ve Schewe'nin (2011) meta-analiz çalışmasına göre yüzeysel duygusal emek ve iş doyumu arasında -.27 düzeyinde bir ilişki varken derin duygusal emek ve iş doyumu arasındaki ilişki anlamsızdır. İş doyumunun duygusal emek tarafından yordanmamış olmasının bir nedeni çalışma verilerinin birden fazla sayıda ve farklı sağlık kuruluşundan toplanmış olması olabilir. İş doyumunu her bir kuruluşun kendi çalışma koşulları da etkilediği için ve kurumdan kuruma bu faktörler de değişiklik barındırdığı için beklenen yönde bulgulara ulaşılamamış olabilir. Ayrıca mevcut çalışmada doktorlardan, hemşirelerden ve tıbbî sekreterlerden veri toplanmıştır. Dolayısıyla her bir grubun iş doyumu için belirleyici olan özlük hakları farklılaşmaktadır ve bu da iş doyumu ile ilgili bulguları etkilemiş olabilir. Gelecek çalışmalarda tek bir sağlık kurumundan (örn. Şehir Hastanesi) ve bu kurumdaki tek bir meslek grubundan (örn. doktorlar veya hemşireler) veri toplanması daha sağlıklı bulgular elde edilmesine katkıda bulunabilir.

Diğer yandan araştırmanın duygusal emek ve psikolojik semptomlar arasındaki ilişkilere yönelik hipotezleri desteklenmiştir. Yüksek yüzeysel duygusal emek ve düşük derin duygusal emek somatizasyon, depresyon ve hostilite semptomlarındaki artışla ilişkili bulunmuştur. Alan yazında yer alan çeşitli araştırma bulguları da özellikle yüzeysel duygusal emeğin öznel iyi oluş üzerindeki olumsuz etkilerini ortaya koymuştur (Hülsheger \& Schewe, 2011; Humphrey, Ashforth ve Diefendorff, 2015). Xanthopoulou, Bakker, Oerlemans ve Koszucka (2018) yürüttükleri güncel günlük çalışmasında gün içinde sergilenen yüzeysel duygusal emeğin günün sonunda ölçümlenen öznel iyi oluşu olumsuz etkilediğini, günlük derin duygusal emeğin ise olumlu etkilerinin olduğunu tespit etmişlerdir. Hizmet çalışanlarının kendi duyguları üzerinde gün boyu kontrol ve denetim sağlama çabaları sınırlı miktarda bulunan düzenleyici kaynakların tükenmesine (ego tükenmesi-ego depletion) neden olmaktadır (Muraven ve Baumeister, 2000). Judge, Woolf ve Hurst (2009) duygusal emek ve çalışan esenliği arasındaki ilişkileri düzenleyen değişkenler olarak dışadönüklüğü ve nevrotikliği tespit etmişlerdir. Dişadönüklükte yüksek ve nevrotiklikte düşük olan kişiler, gün 
içinde sergilenen duygusal emek davranışlarının esenlik üzerindeki olumsuz yansımalarından daha az etkilenmektedirler. Ancak bu özellikler kişilik özellikleri oldukları için görece durağandırlar ve duygusal emeğin olumsuz etkileriyle baş etmek için değiştirilebilmeleri mümkün değildir. Diestel, Rivkin ve Schmidt'in (2015) günlük çalışması, uyku kalitesinin ve öz kontrol kapasitesinin duygusal emeğin olumsuz sonuçlarına karşı koruyucu unsurlar olduğunu göstermiştir. Araştırmacılar, örgütler tarafından uyku hijyenine yönelik eğitim programlarının (örn., Brown, 2004) ve öz kontrolü artırmaya yönelik müdahale programlarının (Oaten ve Cheng, 2007) uygulanmasının çalışanların öznel iyi oluşuna olumlu katkıda bulunabileceğini öne sürmektedirler. Benzer şekilde çalışanların gün içindeki enerji kaynaklarını artırmaya ve korumaya yönelik başka müdahale programları da uygulanabilir. Örneğin egzersizler, nefes teknikleri ile gevşeme ve bilişsel yeniden programlama eğitimleri (Munz, Kohler ve Greenberg, 2001) veya bilinçli farkındalık pratikleri (Hülsheger, Alberts, Feinholdt ve Lang, 2013) bu amaçla başvurulabilecek müdahale programları arasında yer almaktadır. Bunlara ek olarak çalışanlara duygu düzenleme, stresle baş etme, çatışma çözme, empati ve perspektif alma gibi konularda bilgi ve farkındalık artırıcı eğitimler uygulanmasının da faydalı olacağı düşünülmektedir.

$\mathrm{Bu}$ araştırmanın üç temel sınırlılı̆̆ bulunmaktadır. İlk olarak çalışmanın verileri öz beyana dayalıdır. $\mathrm{Bu}$ nedenle ortak faktör varyansı artmış (Podsakoff, MacKenzie ve Podsakoff, 2012) ve farklı kavramlara yönelik ölçümler arasındaki ilişkiler gerçekte olduğundan daha fazla çıkmış olabilir (Çizel, Selçuk ve Atabay, 2020). İkinci sınırlılık araştırma bulgularının genellenebilirliği ile ilgilidir. Bu çalışmada veriler hastanelerde görev yapan sağlık personelinden toplanmıştır. Hizmet sektöründe ancak farklı mesleklerde çalışan katılımcı grupları için araştırmada ele alınan değişkenler arasındaki ilişki örüntüleri farklılık arz edebilir. Benzer çalışmaların farklı örgütlerdeki ve mesleklerdeki kişiler üzerinde tekrarlanmasında fayda bulunmaktadır. Son olarak bu araştırma kesitsel bir çalışmadır. Tek bir zaman diliminde katılımcılardan veri toplanmıştır. Bu konuda yürütülecek boylamsal çalışmalar ve özellikle günlük çalışmaları özellikle duygusal emek ve psikolojik esenlik arasındaki ilişkinin doğasının daha iyi anlaşılmasına katkıda bulunabilir. Bu araştırmada da olduğu gibi çoğu araştırmada esenlik, duygusal emeğin bir çıktısı olarak ele alınmaktadır. Yürütülecek günlük araştırmalarında günün sonundaki esenlik düzeyinin bir sonraki günün duygusal emek düzeyini yordayıp yordamadığı incelenebilir.

Özetlemek gerekirse bu çalışmada sağlık sektörü çalışanları için kişiliğin 
dışadönüklük, uyumluluk ve sorumluluk bilinci boyutlarının duygusal emeği yordadığg tespit edilmiştir. Yüzeysel duygusal emeğin çalışanın psikolojik esenliğini olumsuz etkilediği ancak derin duygusal emeğin olumlu etkileri olduğu görülmüştür. Bu bulgular 1şığında sağlık sektöründe çalışacak personelin işe alım sürecinde kişilik testlerinin uygulanması ve böylece duygusal servis performansı daha başarılı adayların seçilmesi düşünülebilir. Ayrıca, çalışanların günlük enerji düzeylerini ve duygu düzenleme kapasitelerini artırabilmek için uyku hijyeni, öz kontrol, nefes teknikleri, gevşeme, bilinçli farkındalık, empati ve perspektif alma gibi konularda müdahale programları uygulanabilir. 


\section{KAYNAKÇA}

Arnold, K. A. (2017). Transformational leadership and employee psychological wellbeing: A review and directions for future research. Journal of Occupational Health Psychology, 22(3), 381-393.

Arnold, K. A. ve Walsh, M. M. (2015). Customer incivility and employee well-being: Testing the moderating effects of meaning, perspective taking and transformational leadership. Work \& Stress, 29, 362-378.

Aslan, Z., ve Arı, G. S. (2018). Kişilik ve duygusal emek arasındaki ilişkilerin belirlenmesi üzerine bir araştırma: Banka çalıșanları örneği. Pamukkale Üniversitesi Sosyal Bilimler Enstitüsü Dergisi, 30, 157-171.

Athota, V.S., Budhwar, P. ve Malik, A. (2020). Influence of personality traits and moral values on employee well-being, resilience and performance: A cross-national study. Applied Psychology: An International Review, 69(3), 653-685.

Barańczuk, U. (2019). The five factor model of personality and emotion regulation: A meta-analysis. Personality and Individual Differences, 139, 217-227.

Barrick, M. R. ve Mount, M. K. (1991). The Big Five personality dimensions and job performance: A meta-analysis. Personnel Psychology, 44, 1-26.

Beğenirbaş, M. ve Yalçın, R. C. (2012). Hizmetkâr liderlik algısının duygusal emek üzerine etkileri: hizmet çalışanları üzerinde bir araştırma. Savunma Bilimleri Dergisi, 19(37), 159-194.

Bilgic, R. (1999). A different way of testing the interaction between core job dimensions and growth need strength (GNS). In J. Axelsson, B. Bergman, \& J. Eklund (Ed.), Proceedings of the International Conference on TQM and Human Factors (sf. 210-215).

Bono, J. E. ve Vey, M. A. (2005). Toward understanding emotional management at work: A quantitative review of emotional labor research. C. E. J. Hartel, W. J. Zerbe, ve N. M. Ashkanasy (Ed.), Emotions in organizational behavior (sf. 213-233). Mahwah, NJ: Lawrence Erlbaum Associates.

Brotheridge, C. M. ve Grandey, A. A. (2002). Emotional labor and burnout: Comparing two perspectives of "people work." Journal of Vocational Behavior, 60, 17-39.

Brotheridge, C. M. ve Lee, R. T. (2003). Development and validation of the emotional labour scale. Journalof Occupational and Organizational Psychology, 76, 365379.

Brown, M. (2004). Taking care of business: Self-help and sleep medicine in American corporate culture. Journal of Medical Humanities, 25, 173-187.

Burger, J. M. ve Caldwell, D. F. (2000). Personality, social activities, job-search behavior and interview success: Distinguishing between PANAS trait positive affect and NEO extraversion. Motivation and Emotion, 24, 51- 62.

Busseri, M. A., Sadava, S. W. ve DeCourville, N. (2007). A hybrid model for research on subjective well-being: Examining common and component-specific sources of variance in life satisfaction, positive affect, and negative affect. Social Indicators Research, 83, 413-445. 
Carmeli, A., Yitzhak-Halevy, M. ve Weisberg, J. (2009). The relationship between emotional intelligence and psychological wellbeing. Journal of Managerial Psychology, 24, 66-78.

Cartwright, S. ve Cooper, G. (2008). Personnel Psychology, New York: Oxford University Press.

Chi, N.-W. ve Grandey, A. A. (2019). Emotional labor predicts service performance depending on activation and inhibition regulatory fit. Journal of Management, 45(2), 673-700.

Costa, P. T., Jr. ve McCrae, R. R. (1989). The NEO-PI/NEO-FFl manual supplement. Odessa. FL: Psychological Assessment Resources.

Costa, P. T., Jr. ve McCrae, R. R. (1992). Revised NEO Personality Inventory (NEO-PI$\mathrm{R})$ and NEO Five Factor Inventory (NEO-FFI) professional manual. Odessa, FL: PAR.

Çizel, B., Selçuk, O. ve Atabay, E. (2020). Ortak Yöntem Yanlılığı Üzerine Sistematik Bir Yazın Taraması. Anatolia: Turizm Araştırmaları Dergisi, 31(1), 7 - 18.

Daniels, K. (2000). Measures of five aspects of affective well-being at work. Human Relations, 53, 275-294.

DeNeve, K. M. ve Cooper, H. (1998). The happy personality: A meta-analysis of 137 personality traits and subjective well-being. Psychological Bulletin, 124, 197229.

Diefendorff, J. M., Croyle, M. H. ve Gosserand, R. H. (2005). The dimensionality and antecedents of emotional labor strategies. Journal of Vocational Behavior, 66, 339-357.

Diener, E., Emmons, R. A., Larsen, R. J. ve Griffin, S. (1985). The satisfaction with life scale. Journal of Personality Assessment, 49, 71- 75.

Diener, E., Suh, E. M., Lucas, R. E.ve Smith, H. L. (1999). Subjective well-being: Three decades of progress. Psychological Bulletin, 125, 276-302.

Diestel, S., Rivkin, W. ve Schmidt, K.-H. (2015). Sleep quality and self-control capacity as protective resources in the daily emotional labor process: Results from two diary studies. Journal of Applied Psychology, 100, 809 - 827.

Erickson, R. J. ve Grove, W. J. C. (2008). Emotional labor and health care. Sociology Compass, 2, 1-30.

Fouquereau, E., Morin, A. J. S., Lapointe, É., Mokounkolo, R. ve Gillet, N. (2019). Emotional labour profiles: Associations with key predictors and outcomes. Work Stress, 33, 268-294.

Gabriel, A. S. ve Diefendorff, J. M. (2015). Emotional labor dynamics: A momentary approach. Academy of Management Journal, 58, 1804-1825.

Gilbreath, B. ve Benson, P. G. (2004). The contribution of supervisor behavior to employee psychological well-being. Work \& Stress, 18(3), 255-266.

Grandey, A.A. (1999). The Effects of Emotional Labor: Employee Atitudes, Stress and Performance. Yayınlanmış doktora tezi, Colorado State Unıversity, Colorado. 
Grandey, A. A. (2000). Emotion regulation in the workplace: A new way to conceptualize emotional labor. Journal of Occupational Health Psychology, 5, 95-110.

Grandey, A. A. (2003). When "the show must go on": Surface and deep acting as determinants of emotional exhaustion and peer-rated service delivery. Academy of Management Journal, 46, 86-96.

Grandey, A. A. ve Diamond, J. A. (2010). Interactions with the public: Bridging job design and emotional labor perspectives. Journal of Organizational Behavior, $31,338-350$.

Grandey, A. A., Chi, N. W. ve Diamond, J. A. (2013). Show me the money! Do financial rewards for performance enhance or undermine the satisfaction from emotional labor? Personnel Psychology, 66, 569-612.

Grandey, A., Diefendorff, J. ve Rupp, D. E. (2013). Emotional labor in the 21st century: Diverse perspectives on emotion regulation at work. New York, NY: Routledge.

Gross, J. J. (1998). The emerging field of emotion regulation: An integrative review. Review of General Psychology, 2, 271-299.

Gross, J. J. (2015). Emotion regulation: Current status and future prospects. Psychological Inquiry, 26, 1-26.

Hackman, J. R. ve Oldham, G. R. (1975). Development of Job Diagnostic Survey. Journal of Applied Psychology, 60, 159-170.

Heffernan, M. ve Dundon, T. (2016). Cross-level effects of high-performance work systems (HPWS) and employee well-being: the mediating effect of organizational justice. Human Resource Management Journal, 26(2), 211-231.

Higgins, E. T. (1998). Promotion and prevention: Regulatory focus as a motivational principle. Advances in Experimental Social Psychology, 30, 1- 45.

Hochschild, A. (1979). Emotion work, feeling rules, and social structure. American Journal of Sociology, 85, 551-575.

Hochschild, A. (1983). Comment on Kemper's "social constructionist and positivist approaches to the sociology of emotions". American Journal of Sociology, 89(2):432-34.

Humphrey, R. H., Ashforth, B. E. ve Diefendorff, J. M. (2015). The bright side of emotional labor. Journal of Organizational Behavior, 36, 749-769.

Hülsheger, U. R., Alberts, H. J. E. M., Feinholdt, A. ve Langer, J. W. B. (2013). Benefits of mindfulness at work: The role of mindfulness in emotion regulation, emotional exhaustion, and job satisfaction. Journal of Applied Psychology, 98(2), 310-325.

Hülsheger, U. R. ve Schewe, A. F. (2011). On the costs and benefits of emotional labor: A meta-analysis of three decades of research. Journal of Occupational Health Psychology, 16, 361-389.

John, O. P., Donahue, E. ve Kentle, R. L. (1992). The Big Five Inventory: Versions 4a and 54. Technical Report, Berkeley: University of California at Berkeley, Institute of Personality Assessment and Research.

Judge, T. A., Bono, J. E., Ilies, R. ve Gerhardt, M. W. (2002). Personality and leadership: A qualitative and quantitative review. Journal of Applied Psychology, 87, 765-780. 
Judge, T. A., Heller, D. ve Mount, M. K. (2002). Personality and job satisfaction: A metaanalysis. Journal of Applied Psychology, 87, 530-541.

Judge, T. A., Woolf, E. F. ve Hurst, C. (2009). Is emotional labor more difficult for some than for others? A multi-level, experience-sampling study. Personnel Psychology, 62, 5788 .

Kammeyer-Mueller, J. D., Rubenstein, A. L., Long, D. M., Odio, M. A., Buckman, B. R. (2013). A meta-analytic structural model of dispositional affectivity and emotional labor. Personnel Psychology, 66, 47-90.

Karim, J. ve Weisz, R. (2011). Emotional intelligence as a moderator of affectivity/emotional labor and emotional labor/psychological distress relationships. Psychological Studies, 56, 348-359.

Kaya, Ş. D. ve Yüceler, A. (2013). The concept of emotional labor in health sector, Mediterranean Journal of Social Sciences, 4(9), 775-779.

Keyes, C. L. M. (2006). Subjective well-being in mental health and human development research worldwide: An introduction. Social Indicators Research, 77, 1-10.

Keyes, C. L. M. (2007). Promoting and protecting mental health as flourishing: A complementary strategy for improving national mental health. American Psychologist, 62, 95-108.

Keyes, C. L. M., Shmotkin, D. ve Ryff, C. D. (2002). Optimizing well-being: The empirical encounter of two traditions. Journal of Personality and Social Psychology, 82(6), $1007-1022$.

Kiffin-Petersen, S. A., Jordan, C. L. ve Soutar, G. N. (2011). The Big Five, emotional exhaustion and citizenship behaviors in service settings: the mediating role of emotional labor. Personality and Individual Differences, 50, 43-48.

Kim, H. J., Shin, K. H. ve Swanger, N. (2009). Burnout and engagement: A comparative analysis using the Big Five personality dimensions. International Journal of Hospitality Management, 28, 96-104.

Lucas, R. E. ve Diener, E. (2015). Personality and subjective wellbeing: current issues and controversies. M. Mikulincer, P. R. Shaver, Cooper ve R. J. Larsen (Ed.), APA handbook of personality and social psychology: Cilt:4. Personality processes and individual differences (sf. 577-599). Washington, DC: American Psychological Association.

McCrae, R. R. ve Costa, P. T., Jr. (1991). The NEO Personality Inventory: Using the fivefactor model in counseling. Journal of Counseling and Development, 69, 367-372.

Magnus, K., Diener, E., Fujita, F. ve Pavot, W. (1993). Extraversion and neuroticism as predictors of objective life events: A longitudinal analysis. Journal of Personality and Social Psychology, 65, 1046-1053.

Miller, D. J., Vachon, D. D. ve Lynam, D. R. (2009). Neuroticism, negative affect, and negative affect instability: Establishing convergent and discriminant validity using ecological momentary assessment. Personality and Individual Differences, 47, 873877.

Miner, J. B. ve Raju, N. S. (2004). Risk propensity differences between managers and entrepreneurs and between low and high growth entrepreneurs: A reply in a more 
conservative vein. Journal of Applied Psychology, 89, 3-13.

Molinsky, A. ve Margolis, J. (2005). Necessary evils and inter personal sensitivity in organizations. Academy of Management Review, 30: 245-268.

Muraven, M. ve Baumeister, R. F. (2000). Self-regulation and depletion of limited resources: Does self-control resemble a muscle? Psychological Bulletin, 126, 247-259.

Munz, D., Kohler, J. ve Greenberg, C. (2001). Effectiveness of a comprehensive worksite management program: Combining organisational and individual interventions. International Journal of Stress Management, 8, 49-62.

Oaten, M. ve Cheng, K. (2007). Improvements in self-control from financial monitoring. Journal of Economic Psychology, 28, 487-501.

Öz-Ünler, E. (2007). Duygusal Emek Davranışlarının İş Sonuçlarına Etkisi. İstanbul: Beta Yayınc1lik.

Page, K. M. ve Vella-Brodrick, D. A. (2009). The 'What', 'Why', and 'How' of employee well-being: A new model. Social Indicators Research, 90, 441-458.

Panaccio, A. ve Vandenberghe, C. (2009). Perceived organizational support, organizational commitment and psychological wellbeing: A longitudinal study. Journal of Vocational Behavior, 75, 224-236.

Podsakoff, P. M., MacKenzie, S. B. ve Podsakoff, N. P. (2012). Sources of Method Bias in Social Science Research and Recommendations on How to Control it. Annual Review of Psychology, 63: 539-569.

Riforgiate, S. E., Howes, S. S. ve Simmons, M. J. (2021). The impact of daily emotional labor on health and well-being. Management Communication Quarterly, 35(4).

Salgado, J. F. (2002). The Big Five personality dimensions and counterproductive behaviors. International Journal of Selection and Assessment, 10, 117-125.

Sümer, N. ve Sümer, H. C. (2005). Beş faktör kişilik özellikleri ölçeği (Yayınlanmamış çalışma).

Şahin, N. H. ve Durak, A. (1994). Kısa Semptom Envanteri: Türk gençleri için uyarlaması. Türk Psikoloji Dergisi, 9(31), 44-56.

Tsai, W.-C. (2001). Determinants and Consequences of Employee Displayed Positive Emotions, Journal of Management, 27 (4), 497-512.

Tsai, W. ve Huang, Y. (2002). Mechanisms linking employee affective delivery and customer behavioral intentions. Journal of Applied Psychology, 87(5), 1001-1008.

Venkatesh, J. ve Balaji, J. (2013). The health care initiative for emotional labors, International Journal of Education and Research, 1(1), 1-9.

Wang, G., Seibert, S. E. ve Boles, T. L. (2011). Synthesizing what we know and looking ahead: A meta-analytical review of 30 years of emotional labor research. Research on Emotion in Organizations, 7, 15-43.

Warr, P. (2006). Differential activation of judgments in employee well-being. Journal of Occupational and Organizational Psychology, 79(2), 225-244.

Watson, D. ve Clark, L. A. (1992). On traits and temperament: General and specific factors of emotional experience and their relation to the five factor model. Journal of Personality, 60, 441-476. 
Watson, D., Clark, L. A. ve Tellegen, A. (1988). Development and validation of brief measures of positive and negative affect: The PANAS scales. Journal of Personality and Social Psychology, 54, 1063-107.

Wright, T. A. ve Cropanzano, R. (2000). Psychological well-being and job satisfaction as predictors of job performance. Journal of Occupational Health Psychology, 5, $84-$ 94.

Wright, T. A., Cropanzano, R., Bonett, D. G. ve Diamond, W. J. (2009). The role of employee psychological wellbeing in cardiovascular health: When the twain shall meet. Journal of Organizational Behavior, 30, 193-208.

Xanthopoulou, D., Bakker, A. B., Oerlemans, W. G. M. ve Koszucka, M. (2018). Need for recovery after emotional labor: Differential effects of daily deep and surface acting. Journal of Organizational Behavior, 39, 481-494.

Yetim, Ü. (1993). Life satisfaction: A study based on the organization of personal projects. Social Indicators Research, 29, 277-289.

Zhao, H. ve Seibert, S. E. (2006). The big five personality dimensions and entrepreneurial status: A meta-analytical review. Journal of Applied Psychology, 91: 259-271. 
Tablo 1. Betimleyici istatistikler

\begin{tabular}{|c|c|c|c|c|c|c|c|c|c|c|c|c|c|c|c|}
\hline & & 1 & 2 & 3 & 4 & 5 & 6 & 7 & 8 & 9 & 10 & 11 & 12 & 13 & 14 \\
\hline 1. & Cinsiyet & - & & & & & & & & & & & & & \\
\hline 2. & Yaş & $.20^{* *}$ & - & & & & & & & & & & & & \\
\hline 3. & Nevrotiklik & -.03 & -.13 & .68 & & & & & & & & & & & \\
\hline 4. & Dışadönüklük & -.01 & -.03 & $-.30^{* *}$ & .72 & & & & & & & & & & \\
\hline 5. & Deneyime Açıklık & -.06 & -.03 & $-.26^{* *}$ & $.58^{* * *}$ & .75 & & & & & & & & & \\
\hline 6. & Uyumluluk & $-.21^{* * *}$ & .09 & $-.47^{* *}$ & $.29^{* *}$ & $.48^{* *}$ & .67 & & & & & & & & \\
\hline 7. & Sorumluluk Bilinci & $-.22^{* *}$ & $.15^{*}$ & $-.47^{* *}$ & $.36^{* *}$ & $.47^{* *}$ & $.64^{* *}$ & .74 & & & & & & & \\
\hline 8. & Yüzeysel Duygusal Emek & .13 & -.01 & .02 & $.18^{* *}$ & .03 & $-.14^{*}$ & -.09 & .82 & & & & & & \\
\hline 9. & Derin Duygusal Emek & -.06 & .08 & $-.32^{* *}$ & $.35^{* *}$ & $.37^{* *}$ & $.40^{* *}$ & $.41^{* *}$ & $.23^{* *}$ & .74 & & & & & \\
\hline 10. & Yaşam Doyumu & -.02 & $.16^{*}$ & -.08 & .10 & .00 & .05 & $.15^{*}$ & $-.13^{*}$ & .05 & .82 & & & & \\
\hline 11. & İş Doyumu & .02 & .07 & -.10 & $.17^{*}$ & .02 & .04 & .02 & .01 & .08 & $.57^{* *}$ & .72 & & & \\
\hline 12. & Somatizasyon & $-.14^{*}$ & $-.13^{*}$ & $.30^{* *}$ & -.08 & -.11 & $-.29^{* *}$ & $-.21^{* *}$ & $.22^{* *}$ & -.06 & $-.14^{*}$ & $-.13^{*}$ & .86 & & \\
\hline 13. & Depresyon & -.10 & -.11 & $.35^{* *}$ & $-.19^{* * *}$ & -.12 & $-.25^{* *}$ & $-.26^{* *}$ & $.15^{*}$ & $-.16^{*}$ & $-.25^{* *}$ & $-.16^{*}$ & $.73^{* *}$ & .86 & \\
\hline \multirow[t]{3}{*}{14.} & Hostilite & -.02 & $-.15^{*}$ & $.41^{* *}$ & $-.14^{*}$ & -.09 & $-.41^{* *}$ & $-.29^{* *}$ & $.18^{* *}$ & $-.17^{*}$ & $-.16^{*}$ & $-.15^{*}$ & $.69^{* *}$ & $.72^{* *}$ & .81 \\
\hline & Ortalama & - & 30.58 & 2.65 & 3.66 & 3.78 & 4.00 & 3.97 & 3.04 & 4.01 & 3.82 & 3.74 & 0.91 & 1.04 & 1.10 \\
\hline & Standart Sapma & - & 9.16 & 0.70 & 0.75 & 0.64 & 0.64 & 0.66 & 0.92 & 0.90 & 1.34 & 1.41 & 0.90 & 0.95 & 0.95 \\
\hline
\end{tabular}

$* p<.05 * * p<.01$. Güvenirlik katsayıları köşegende sunulmaktadır.

Tablo 2. Duygusal Emek için standart çoklu regresyon sonuçları

\begin{tabular}{lcccccc}
\hline \multirow{2}{*}{ Bağımsız Değişken } & \multicolumn{3}{c}{ Yüzeysel Duygusal Emek } & \multicolumn{3}{c}{ Derin Duygusal Emek } \\
& $\beta$ & $S H$ & $t$ & $\beta$ & $S H$ & \multicolumn{1}{c}{$t$} \\
\hline Sabit değer*** & 3.43 & .69 & $4.96^{* *}$ & 1.29 & .60 & $2.15^{*}$ \\
Nevrotiklik & -.02 & .10 & -.29 & -.09 & .09 & -1.31 \\
Dişadönüklük & .26 & .10 & $3.22^{* *}$ & .16 & .09 & $2.17^{*}$ \\
Deneyime Açılklık & -.00 & .13 & -.05 & .10 & .11 & 1.32 \\
Uyumluluk & -.16 & .13 & $-1.78^{\dagger}$ & .17 & .11 & $2.06^{*}$ \\
Sorumluluk Bilinci & -.10 & .13 & -1.07 & .16 & .11 & $1.97^{*}$ \\
& & & .08 & & .25 \\
\hline
\end{tabular}

${ }^{\dagger} p<.10 * p<.05 * * p<.01 * * *$ Sabit değer için standart olmayan regresyon katsayıları sunulmuştur.

Tablo 3. Yaşam ve İş Doyumu için standart çoklu regresyon sonuçları

\begin{tabular}{lcccccc}
\hline \multirow{2}{*}{ Bă̆ımsız Değişken } & \multicolumn{3}{c}{ Yaşam Doyumu } & \multicolumn{3}{c}{ İş Doyumu } \\
& $\beta$ & SH & $t$ & $\beta$ & $S H$ & \multicolumn{1}{c}{$t$} \\
\hline Sabit değer*** & 3.99 & .46 & $8.73^{* *}$ & 3.23 & .48 & $6.69 * *$ \\
Yüzeysel Duygusal Emek & -.15 & .10 & $-2.25^{*}$ & -.01 & .11 & -.07 \\
Derin Duygusal Emek & .09 & .10 & 1.26 & -.08 & .11 & 1.24 \\
& & & .02 & & .01 \\
\hline
\end{tabular}


Mersin Üniversitesi Sosyal Bilimler Enstitüsü e-Dergisi

Cilt: 5 Sayı:1/Aralık 2021

$* p<.05 * * p<.001 * * *$ Sabit değer için standart olmayan regresyon katsayıları sunulmuştur.

Tablo 4. Psikolojik semptomlar için standart çoklu regresyon sonuçları

\begin{tabular}{lcccccccccc}
\hline \multirow{2}{*}{ Bağımsız Değişken } & \multicolumn{3}{c}{ Somatizasyon } & \multicolumn{3}{c}{ Depresyon } & \multicolumn{3}{c}{ Hostilite } \\
& $\beta$ & $S H$ & $t$ & $\beta$ & $S H$ & $t$ & & $S H$ & $t$ \\
\hline Sabit değer **** & .66 & .30 & $2.23^{*}$ & 1.31 & .32 & $4.16^{* * *}$ & 1.32 & .31 & $4.26^{* * *}$ \\
Yüzeysel Duygusal Emek & .24 & .06 & $3.66^{* * *}$ & .20 & .07 & $3.04 * *$ & .23 & .07 & $3.54^{* * *}$ \\
Derin Duygusal Emek & -.12 & .07 & $-1.77^{\dagger}$ & -.21 & .07 & $-3.18^{* *}$ & -.22 & .07 & $-3.39 * *$ \\
& & & .06 & & & .07 & & .08 \\
\hline
\end{tabular}

${ }^{\dagger} p<.10 * p<.05 * * p<.01 * * * p<.001 * * *$ Sabit değer için standart olmayan regresyon katsayıları sunulmuştur. 